\title{
Squamous Cell Carcinoma
}

National Cancer Institute

\section{Source}

National Cancer Institute. Squamous Cell Carcinoma. NCI Thesaurus. Code C2929.

A carcinoma arising from squamous epithelial cells. Morphologically, it is characterized by the proliferation of atypical, often pleomorphic squamous cells. Squamous cell carcinomas are graded by the degree of cellular differentiation as well, moderately, or poorly differentiated. Well differentiated carcinomas are usually associated with keratin production and the presence of intercellular bridges between adjacent cells.

Representative examples are lung squamous cell carcinoma, skin squamous cell carcinoma, and cervical squamous cell carcinoma. 